\title{
Ownership structure and profitability of listed firms in an emerging market
}

\author{
Richard Angelous Kotey ${ }^{a^{*}}$, Baah Kusi ${ }^{\mathrm{a}}$ and Richard Akomatey ${ }^{\mathrm{a}}$
}

${ }^{a}$ Department of Finance, University of Ghana Business School, University of Ghana, Ghana

\begin{tabular}{l}
\hline C H R O N I C L E \\
\hline Article history: \\
Received May 112019 \\
Received in revised format May \\
242019 \\
Accepted June 32019 \\
Available online \\
June 32019 \\
\hline Keywords: \\
Ownership structure \\
Profitability \\
Listed firms \\
Ghanaian firms
\end{tabular}

\section{A B S T R A C T}

\begin{abstract}
Motivated by the agency theory and the need to examine the effect of separation of ownership and management, this study examines the determinants of profitability in different firm ownership structures and how different ownership structures impact the profitability of listed firms between 2003 and 2013, using pooled annual data of 23 Ghanaian listed firms. Employing a number of static models (OLS, Random Effects and 3 Stage Least Squares), we find evidence that while profit determinants vary for listed firms given their ownership structures, ownership structures also affected profitability differently. Specifically, for listed firms, profitability was determined by capital intensity, liquidity, financial risk, age and GDP; for non-family owned listed firms, profitability was determined by capital intensity, liquidity, market share and age; for foreign-owned firms, profitability was determined by capital intensity, liquidity, age and GDP; and for non-foreign ownership, profitability was determined by capital intensity, liquidity, financial risk, growth, age and GDP. When we examine the impact of ownership structure on profitability and find that family-owned listed firms make 30\% less profits compared to nonfamily owned ones, whilst foreign-owned firms make $13 \%$ more profits than non-foreign owned ones. These findings confirm the agency theory which posits that separation of ownership and management, though may lead to agency problems, can positively affect profits. The study recommends that family-owned listed firms should consider diluting ownership in order to grow more profits.
\end{abstract}

C 2020 by the authors; licensee Growing Science, Canada

\section{Introduction}

Following the seminal papers by Bearle and Means (1932) and Jensen and Meckling (1976), more scholars have committed time into research in the area of corporate structure and firm performance, exploring the links between ownership and profitability (Morck et al., 1988; McConnell \& Servaes 1990, Altunbas et al., 2001; Iannotta et al., 2007; Yu, 2013; Balsmeier \& Czarnitzki, 2017). The agency theory justifies the need for separation of ownership and management, proving that separation is critical for growth and profitability. However, it became clear with time that the theory had its own weaknesses (Bearle \& Means, 1932; Gedajlovic \& Shapiro, 2002). Back then, the emerging rhetoric was managers were susceptible in diverting firm resources to personal gains, at the expense of shareholders, which came to be termed as agency problem (Jensen \& Meckling, 1976; Gedajlovic \& Shapiro, 2002). Thus, management could intentionally make decisions that benefit them as individuals and not the corporation, thereby affecting firm profits. To correct the breakdown of the manager's fiduciary,

* Corresponding author. Tel.: +233541558434

E-mail address: rakotey002@st.ug.edu.gh (R. A. Kotey) 
manager's equity positions were aligned with shareholders (Jensen, 1993). However, this approach also had its challenges; Fama and Jensen (1983) showed that managers with high shareholdings could expropriate firm wealth and influence the board (Han and Suk (1998) also had similar results). Since then, literature has evolved, looking into different ownership structures and their effect on firm performance.

Studies on ownership structure and profitability have defined ownership along two main lines; ownership concentration and ownership nature (Gedajlovic \& Shapiro, 2002; Iannotta et al., 2007). Ownership concentration focuses on the concentration (or dispersal) of ownership among few (or many) bloc owners. Given the concentration of ownership, ownership may differ according to nature, say predominantly government-owned, privately owned, mutually owned or family owned. Some studies have measured ownership using the concentration approach (Gedajlovic \& Shapiro, 2002; Balsmeier \& Czarnitzki, 2017) whilst others have taken the other approach (Kosak \& Cok, 2008) or both (Kapopoulos \& Lazaretou, 2007). Some have also used bank data (Micco et al., 2004; Berger et al., 2005; Iannotta et al., 2007) whilst others listed firms (Kapopoulos \& Lazaretou, 2007). Whilst these have examined the linear effect, others have looked the non-linear effect ownership has with performance or profitability (Yu, 2013; Peck-Ling et al., 2016; Phung \& Mishra, 2016). But, there is generally no consensus on the effect on ownership structure on firm performance; for example even though the property rights hypothesis suggests that private owned firms should perform better in terms of efficiently and profitably than non-private owned firms (Alchian, 1965), Altunbas et al. (2001), using data from German banks, find little evidence to suggest that private owned banks are more efficient than government-owned banks, although the government banks have cost and profit advantage over the privately owned banks. Micco et al. (2004) also find no significant difference between the Return on Assets of government-owned and private owned banks whilst Demsetz and Villalonga (2001) find a similar result using firm data. Berger et al. (2005) also found that privately owned banks perform better in terms of long-term performance than government owned ones. Therefore, there is a need for a critical look at profitability from the lens of foreign and local ownership. In addition, whilst a lot of studies have been done on foreign vs. local ownership, and private vs. government ownership, not much attention has been given to other forms of ownership, say family ownership. This paper seeks to address this gap. Again, while several authors have emphasized the benefits of foreign firms to developing economies, there is still very little evidence on the impact of foreign firms on firm performance in developing economies (Fries \& Taci, 2005; Iannotta et al., 2007). The paper is unique in that it looks at the effect of two pairs of ownership forms on profitability in an emerging economy using data on listed firms.

This paper seeks to investigate the relationship between ownership structure (Family owned vs. Nonfamily owned, and Foreign vs. Non-foreign owned) and profitability of listed firms on the Ghanaian Stock Market.

The paper is organized as follows; the next chapter explores existing literature in the research area, bringing out relevant supporting theories; then followed is the methodological approach incorporated in the study; then the analysis and findings are elaborated; finally, the study is concluded with a summary of findings and recommendations.

\subsection{Theoretical review}

The theoretical literature for our variables of interest (ownership structure variables) is agency theory. Agency theory is the most widely used theoretical framework for studies bordering on ownership structure- profitability relationships (Gedajlovic \& Shapiro, 2002; Shleifer \& Vishny, 1997). This theory identifies the necessity of separation of ownership and management; because their roles are not necessary in tandem. Therefore, for businesses to thrive, there must be a clear distinction of the roles. This separation influences corporate behavior and control (Milgrom \& Roberts, 1992). Agency theory 
provides the framework on which managers and shareholders incentives and its effects can be critically examined (Eisenhardt, 1989). Agency theory has been well criticized for its lack of contextualization of principal-agent relations (Hamilton \& Biggart, 1988; Gedajlovic \& Shapiro, 2002). Giving the view of separation of ownership and management, its influence on firm profits, we hypothesize that ownership structure does affect firm profitability.

The theoretical literature on our control variable is based on the economies and diseconomies of scale and scope (Kusi et al., 2017; Terraza, 2015; Naceur \& Orman, 2011; Dietrich \& Wanzenried, 2011; Athanasoglou et al., 2008). The economies and diseconomies of scale and scope are two opposing views on how size affects the performance of firms; economies of scale posits that when a firm begins to grow and expand, its marginal cost reduces and the improves its profits -thus, there are benefits with an increase in firm size (Terraza, 2015) - whilst diseconomies of scale posits that when a firm grows beyond a certain point, its efficiency begins to fall (Kasman, 2010; Terraza, 2015). Authors in favour of economies of scale associated lower operational cost, market power, brand vitalization and consumer perception as the main attributes (Terraza, 2015). Authors in favour of diseconomies of scale have also linked bureaucratic tendencies, duplication of roles, lack of touch with consumers, and low monitoring to resulting in a fall in revenues though the firm may be growing in size. Given the opposing views, we hypothesize that size may have a positive or negative effect on returns.

Under profit maximization, two theories emerge; the first is shareholder profit maximization, which is supported by the shareholder and agency theory (Friedman, 1970; Greene, 1993), whilst the second is the stakeholder profit maximization which is a less dominant theory and quite recent, compared to the former (Freeman, 1984; Freeman and Gilbert, 1988). The shareholder maximization theory advances that businesses exist to make profit for its shareholders alone, and thus managers should only seek that. The stakeholder maximization theory goes beyond the shareholder maximization to advance that businesses should seek the interest of not only shareholders but all stakeholders as well, thus managers have a wider responsibility to all stakeholders. Though the shareholder and stakeholder theories are all value or profit maximization perspectives, their approaches, measurements and understanding of how value should be created and distributed within a firm varies significantly (Kusi et al., 2017; Kochan \& Rubinstein, 2000). Hence, considering how our control variables are measured, it is possible for the respective control variables to have varying effects on profitability.

\subsection{Empirical review}

Scholarly papers on the profitability- ownership structure relationship have principally used firm-level data of banks and listed firms. We elaborate on a number of these studies that have motivated our research;

Iannotta et al. (2007) explored the impact of alternative ownership models and ownership concentration on bank profitability, cost efficiency and risk using a 5-year data from 181 large banks situated in 15 countries in Europe. After controlling for country and time effects as well as bank characteristics, they found that government-owned and mutually banks exhibited lower profitability than their private counterparts, even though government banks had lower costs. With respect to risk, government banks had higher insolvency and lower loan quality than the others whilst mutual banks had lower asset risk and better loan quality. Upon looking at the impact of ownership concentration on profitability, they did not find a significant result. However, their results showed that higher ownership concentration positively affected loan quality and negatively affected asset and insolvency risk.

$\mathrm{Yu}$ (2013) also examined the non-linear impact between state ownership and firm performance using an 8-year annual panel data of over 10,500 non-financial listed on the Chinese stock exchange. He found out that state ownership has a U-shaped relationship with firm performance meaning state-owned firms are profitable only in the long run. This finding adds to Iannotta et al. (2007) who only looked at the linear effect and there saw that firm performance and state ownership were negatively correlated. 
$\mathrm{Yu}$ (2013) however attributed the positive long-run relationship to structural reforms from 2005 to 2006. His results also revealed that higher levels of state ownership was better compared to a dispersed ownership structure due to the benefits they get (like political connections and government support). A second reason was that government-owned firms were in strategic profit-oriented areas like oil and gas, mining, media and others. Iannotta et al. (2007) did not clearly bring this out even though they stated that government-owned banks had lower costs than the others did.

In 2016, Peck-Ling et al. (2016) following from Yu (2013) also used a big 12-year panel data of 4,176 firm-year observations of 348 Malaysia listed companies to examine the impact of foreign equity ownership, appointments of foreign chairman and foreign chief executive director on firm profitability. Using a fixed-effect regression model, they found out that foreign equity ownership did not have any significant effect on profitability but an increase in the number of foreign board members significantly improved profitability. Further results showed profitability improved only when foreign owners had controlling interests in the firm.

Bokpin (2013) also looked at the effect of bank ownership structure and corporate governance on bank efficiency in the Ghanaian context. Using a 9-year annual panel data, he found out that foreign banks were more cost-efficient than domestic banks albeit not necessarily more profitefficient. Nevertheless, he found that foreign banks had better loan quality and were more profitable than their domestic counterparts. He also found a positive link between managerial ownership and banks with inside ownership had better loan quality albeit not profitable. Governance was seen to significantly improve profitability whilst slightly hampering cost efficiency. Capital adequacy ratio and bank size were both significant predictors of efficiency within the Ghanaian banks.

Using a large 6-year panel data of 2744 firm-year observations of listed Vietnamese firms, Phung and Mishra (2016) also examined the non-linear effect of ownership structure on firm performance. Similar to the findings of $\mathrm{Yu}$ (2013), they found a non-linear relationship between ownership structure and firm performance; state ownership exhibited a convex or U-shape relationship with firm performance whilst foreign ownership exhibited a concave or inverse-U relationship with firm performance.

Balsmeier and Czarnitzki (2017) also analyzed the relationship between ownership concentration and firm performance factoring in institutional environments from 2002 to 2009 for 28 Central and Eastern European transition economies. Unlike Phung and Mishra (2016), they found the relationship between ownership concentration and firm performance from non-EU and less developed countries to be an inverted u-shape.

Xia and Walker (2014) also conduct a similar study on manufacturing firms in mainland China using data from 1998 to 2007 to find the extent ownership affects firm performance, whilst factoring in industry, region, firm size, year, and the firm itself as control variables. They found that ownership was significant and pervasive across regions and interacts with both geography and time, reflecting China's decentralized system and the strong trend in privatization.

Mangena et al. (2012) also studied the relationship between ownership and board structure on firm performance in a turbulent political and economic environment. Using a 6-year panel data of firm-level listed Zimbabwean firms, splitting it into the pre-presidential election period (2000-2002) and postpresidential election period (2003-2005) to capture the differences, they found that board size and ownership concentration positively affected performance only in the post-election period. Internal ownership negatively affected performance in the post-election period but is reversed in the pre-election period. The relationship between non-executive directors and performance was negative and significant in both periods. 
Demsetz and Villalonga (2001) also did a similar study investigating the relationship between the ownership structure and performance but treated ownership uniquely as a multi-dimensional endogenous variable. They found no statistically significant relationship between performance and ownership structure thus confirming the view that ownership diffusion, while it may cause agency problem, does provide compensating rewards that offset such problems.

Examining the relationship between the ownership structure and financial performance on 334 Japanese corporations from 1986 to 91, Gedajlovic and Shapiro (2002) found a positive relationship between ownership concentration and financial performance, which is consistent with agency theory postulations. In addition, they observed a more pronounced profit redistribution effect where profitable firms were transferring their financial resources to less profitable ones, perhaps to revive them.

Kapopoulos and Lazaretou (2007) also investigated whether variations in firm's ownership structures affected firm performance on a data of 175 listed firms in Greece. Following Demsetz and Villalonga (2001) they modeled ownership structure as an endogenous variable measuring ownership structure using two different approaches that reflected shareholders conflicting interests. They found that the more concentrated an ownership structure is, the more positive it relates to profitability and higher firm profitability required a less diffused ownership.

These empirical findings discussed here provide evidence of the importance of ownership structure and how it may influence profitability and therefore may have significant policy implications. It is on this backdrop that we conduct our studies.

\section{Methodology}

A panel data framework which consists of both time series and cross-sectional data is employed for the study. The data consist of 23 listed companies across industries over 11 years (2003-2013) with annual frequency. An added benefit to the panel nature of the data is that it controls for both time and firmlevel variations as well as omitted variable biases (Wooldridge, 2009; Brooks, 2008). Secondary data on the listed firms were obtained from the annual financial statements whilst GDP (also in yearly frequency), our only macroeconomic variable, were obtained from the World Development Indicators (WDI) database. The panel data is modeled as;

$$
Y_{i t}=\alpha_{i}+\beta X_{i t}+\varepsilon_{i t}
$$

where: Subscript i signifies the cross-sectional dimension (firms) $\mathrm{i}=1 \ldots N$ and $\mathrm{t}$ signifies the time series dimension (time), $\mathrm{t}=1 \ldots \mathrm{T} ; Y_{i t}$ is the dependent variable; $\alpha_{i}$ is scalar and constant term for all periods $(\mathrm{t})$ and specific to a firm fixed effect $(i) ; \beta$ is $a k \times 1$ vector of parameters to be estimated on the independent variables; Xit is a $1 \times \mathrm{k}$ vector of observations on the independent variables comprising of input variables in the model which includes controlled variables and eit which is iid is the error term.

The study employs mainly a static estimation strategy. Specifically, random effects and random effects with robust standard errors are used to ensure consistency and reliability in the results and findings. The static models estimated are expressed as:

Model 1: Fixed or Random effects

$$
\begin{gathered}
\text { roe }_{i t}=\partial_{i}+\beta_{1} \text { Size }_{i t}+\beta_{2} \text { Captial intensity }_{i t}+\beta_{3} \text { Liquidity }_{i t}+\beta_{4} \text { Financial risk }_{i t} \\
+\beta_{5} \text { Growth }_{i t}+\beta_{6} \text { Marketshare }_{i t}+\beta_{7} \text { Age }_{i t}+\beta_{8} \text { GDP }_{i t}+\varepsilon_{i t}
\end{gathered}
$$

Model 2: Fixed or Random effects with robust standard errors

$$
\begin{aligned}
& \text { roe }_{i t}=\partial_{i}+\beta_{1} \text { Size }_{i t}+\beta_{2} \text { Captial intensity }_{i t}+\beta_{3} \text { Liquidity }_{i t}+\beta_{4} \text { Financial risk }_{i t}+ \\
& \beta_{5} \text { Growth }_{i t}+\beta_{6} \text { Marketshare }_{i t}+\beta_{7} \text { Age }_{i t}+\beta_{8} G D P_{i t}+\varepsilon_{i t}
\end{aligned}
$$

Model 3: Fixed or Random effects on non-family owned firms 


$$
\begin{gathered}
\text { roe }_{i t}=\partial_{i}+\beta_{1} \text { Size }_{i t}+\beta_{2} \text { Captial intensity }_{i t}+\beta_{3} \text { Liquidity }_{i t}+\beta_{4} \text { Financial risk }_{i t} \\
+\beta_{5} \text { Growth }_{i t}+\beta_{6} \text { Marketshare }_{i t}+\beta_{7} \text { Age }_{i t}+\beta_{8} \text { GDP }_{i t}+\varepsilon_{i t}
\end{gathered}
$$

Model 4: Fixed or Random effects of foreign-owned firms

$$
\begin{gathered}
\text { roe }_{i t}=\partial_{i}+\beta_{1} \text { Size }_{i t}+\beta_{2} \text { Captial intensity }_{i t}+\beta_{3} \text { Liquidity }_{i t}+\beta_{4} \text { Financial risk }_{i t} \\
+\beta_{5} \text { Growth }_{i t}+\beta_{6} \text { Marketshare }_{i t}+\beta_{7} \text { Age }_{i t}+\beta_{8} \text { GDP }_{i t}+\varepsilon_{i t}
\end{gathered}
$$

Model 5: Fixed or Random effects on non-foreign owned firms

$$
\begin{aligned}
& \text { roe }_{i t}=\partial_{i}+\beta_{1} \text { Size }_{i t}+\beta_{2} \text { Captial intensity }_{i t}+\beta_{3} \text { Liquidity }_{i t}+\beta_{4} \text { Financial risk }_{i t}+ \\
& \beta_{5} \text { Growth }_{i t}+\beta_{6} \text { Marketshare }_{i t}+\beta_{7} \text { Age }_{i t}+\beta_{8} G D P_{i t}+\varepsilon_{i t}
\end{aligned}
$$

\begin{tabular}{|c|c|c|c|c|}
\hline Symbol & Meaning and interpretation & Source & Underlying theory & $\begin{array}{c}\text { Expected } \\
\text { Sign }\end{array}$ \\
\hline $\begin{array}{l}\text { ROE } \\
\text { (Dependent } \\
\text { Variable) }\end{array}$ & $\begin{array}{l}\text { Return on equity. Measures the returns management get } \\
\text { from the total equity invested by shareholders. It is measured } \\
\text { as; } \\
\qquad R O E=\frac{\text { Net profit }}{\text { Equity }}\end{array}$ & $\begin{array}{l}\text { Financial statements of } \\
\text { listed firms }\end{array}$ & $\begin{array}{l}\text { Shareholder } \\
\text { Theory }\end{array}$ & \\
\hline $\begin{array}{l}\text { SIZE } \\
\text { (Control Variable) }\end{array}$ & $\begin{array}{l}\text { Natural logarithm of total assets. Variable is used as a proxy } \\
\text { to measure the size of the firm. }\end{array}$ & $\begin{array}{l}\text { Financial statements of } \\
\text { listed firms }\end{array}$ & $\begin{array}{l}\text { Economies and } \\
\text { Diseconomies of } \\
\text { Scale and Scope } \\
\text { theory }\end{array}$ & $+\mathrm{ve}$ \\
\hline $\begin{array}{l}\text { Capital intensity } \\
\text { (Control Variable) }\end{array}$ & $\begin{array}{l}\text { Capital intensity is the assets to sales ratio. Measured by; } \\
\qquad \text { Cap int }=\frac{\text { Total Assets }}{\text { Sales }}\end{array}$ & $\begin{array}{l}\text { Financial statements of } \\
\text { listed firms }\end{array}$ & $\begin{array}{l}\text { Economies and } \\
\text { Diseconomies of } \\
\text { Scale and Scope } \\
\text { theory }\end{array}$ & + ve \\
\hline $\begin{array}{l}\text { Liquidity } \\
\text { (Control Variable) }\end{array}$ & $\begin{array}{l}\text { Measures how quickly the firm is able to meet its short term } \\
\text { needs. Measured as; } \\
\qquad \text { liguidty }=\frac{\text { current assts }}{\text { current liabilities }}\end{array}$ & $\begin{array}{l}\text { Financial statements of } \\
\text { listed firms }\end{array}$ & Profit maximization & + ve \\
\hline $\begin{array}{l}\text { Financial risk } \\
\text { (Control Variable) }\end{array}$ & $\begin{array}{l}\text { Measures the extent to which total assets meets total debts. } \\
\text { Measured by; fin.risk }=\frac{\text { total debt }}{\text { total asset }}\end{array}$ & $\begin{array}{l}\text { Financial statements of } \\
\text { listed firms }\end{array}$ & Profit maximization & -ve \\
\hline $\begin{array}{l}\text { Growth } \\
\text { (Control Variable) }\end{array}$ & $\begin{array}{l}\text { Measured by annual percentage change in total assets. } \\
\text { Variable used as a proxy to measure firm growth. }\end{array}$ & $\begin{array}{l}\text { Financial statements of } \\
\text { listed firms }\end{array}$ & $\begin{array}{l}\text { Economies and } \\
\text { Diseconomies of } \\
\text { Scale and Scope } \\
\text { theory }\end{array}$ & $+/$-ve \\
\hline $\begin{array}{l}\text { Market share } \\
\text { (Control Variable) }\end{array}$ & $\begin{array}{l}\text { Measures firm's market share in the industry. Measured as; } \\
\qquad m r k \text { share }=\frac{\text { Total sales }_{\text {firm }}}{\text { Total sales }} \text { industry }\end{array}$ & $\begin{array}{l}\text { Financial statements of } \\
\text { listed firms and industry } \\
\text { data }\end{array}$ & Profit maximization & + ve \\
\hline $\begin{array}{l}\text { Age } \\
\text { (Control Variable) }\end{array}$ & $\begin{array}{l}\text { Age measures how long the firm has been in operation. } \\
\text { Measured by counting how long since the firm was } \\
\text { registered (year of establishment). }\end{array}$ & $\begin{array}{l}\text { Business registration } \\
\text { documents }\end{array}$ & $\begin{array}{l}\text { Economies and } \\
\text { Diseconomies of } \\
\text { Scale and Scope } \\
\text { theory }\end{array}$ & $+/$-ve \\
\hline $\begin{array}{l}\text { GDP } \\
\text { (Control Variable) }\end{array}$ & $\begin{array}{l}\text { Gross domestic product (GDP). It is the total value of } \\
\text { finished goods and services produced in the country yearly. } \\
\text { We used the logged values of GDP to measure this. }\end{array}$ & World Bank Database & $\begin{array}{l}\text { Economic growth } \\
\text { theory }\end{array}$ & $+/$-ve \\
\hline $\begin{array}{l}\text { Family Ownership } \\
\text { (variable of interest) }\end{array}$ & $\begin{array}{l}\text { Dummy variable for family ownership. Measured } 1 \text { if more } \\
\text { than } 50 \% \text { of shares are controlled by family members and } 0 \\
\text { otherwise. }\end{array}$ & Authors own computation & Agency theory & -ve \\
\hline $\begin{array}{l}\text { Foreign } \\
\text { Ownership } \\
\text { (variable of interest) }\end{array}$ & $\begin{array}{l}\text { Dummy variable for foreign ownership. Measured } 1 \text { if more } \\
\text { than } 50 \% \text { of shares are controlled by foreigners and } 0 \\
\text { otherwise. }\end{array}$ & Authors own computation & Agency theory & + ve \\
\hline
\end{tabular}

We proceed to define all the variables used for the study. Additionally, the measurement, expected signs, underlying theories and source of variables are also presented;

Summary of variables

The dataset used for this study has been uploaded online (DOI: 10.17632/2r3cjr23zt.1) and is available on the Mendeley Database (Kotey et al, 2019).

\section{Empirical results}

\subsection{Summary Statistics}

The table below presents descriptive statistics on the variables used for the study. After conducting preliminary checks and tests, we found that there were some outliers in our data, particularly with our 
ROE data, which skewed our data. Therefore, we manually cleaned them by going through and taking them out before doing all further tests and analysis.

Table 1

Descriptive statistics

\begin{tabular}{lcllcc}
\hline Variables & Observation & \multicolumn{1}{c}{ Mean } & \multicolumn{1}{c}{ Std. Dev. } & Min & Max \\
\hline ROE & 163 & 0.152329 & 0.290775 & -0.98392 & 0.794014 \\
Size & 183 & 7.212988 & 0.774181 & 5.186708 & 8.531479 \\
Capital intensity & 181 & 1.913701 & 9.98855 & 0 & 134.5401 \\
Liquidity & 196 & 1.640193 & 1.583854 & 0.035855 & 9.856872 \\
Financial risk & 182 & 0.6205116 & 0.7484486 & 0.044715 & 8.800874 \\
Growth & 177 & 0.2939499 & 1.75199 & -1 & 20.53846 \\
Market share & 196 & 0.056122 & 0.088779 & $2.16 \mathrm{E}-06$ & 0.356839 \\
Age & 212 & 10.60849 & 6.016764 & 1 & 23 \\
GDP & 212 & 10.36527 & 0.256443 & 9.882661 & 10.67947 \\
Family ownership & 173 & 0.057804 & 0.234049 & 0 & 1 \\
Foreign ownership & 173 & 0.32948 & 0.471389 & 0 & 1 \\
\hline
\end{tabular}

The average ROE for the data set stands at $15.23 \%$ and varies around $29 \%$. The highest ROE in the data was $79 \%$ and the lowest was $-98 \%$ signaling the broad range of returns on equity for our data. We expect to see that because our data contains a wide range of different-sized listed companies.

The average value for the Size variable was 7.21, which fell between 5.18 and 8.53. Considering that the proxy for size is a logged value, we see that the variation on the data has been significantly reduced.

The average Capital Intensity of 1.91 tells us two things; first, total assets exceed total sales averagely which is expected, and secondly, average sales is equal to about two times of total assets. Put differently, the average unit of sales made is attributable to about two units of assets. However, the sales values are very spurious as captured by the large standard deviation and range. Again, we expect to see this because the firms vary in sizes.

The average Liquidity of 1.64 also tells us that the firms have enough current assets to meet their current liabilities; current assets exceed current liabilities by 1.6 to 1 , indicating a good liquidity position. The standard deviation for this variable is also very small which shows little variation from the mean value. In addition, the lower boundary of 0.03 means the firm with the worst liquidity position had an assetliability ratio of 1 to 30 whilst the upper boundary of 9.85 means the firm with the best asset-liability position had an asset-liability ratio of 1 to 0.102 .

An average Financial Risk of $62 \%$ means debt is about $62 \%$ of total assets average. This shows that the firms have large debt proportions as against their assets. Because we did not see this in our liquidity figures, it means these debts are mostly long-term debts; thus the firms in the data sets have large long term debts. The standard deviation of $75 \%$ also indicates that the mean figure is very spurious. The very high upper boundary (maximum value) also indicates the presence of firms with extremely high debt values (outliers) but we do not expect this to significantly affect our findings.

Growth in total assets averaged around $29 \%$ and this figure varied widely as observed by a high standard deviation of $175 \%$. The upper and lower boundaries were also very far apart showing how diverse the growth rate has been for the data set.

The average Market Share was also about 5.6\% for the data set and the standard deviation was $8.9 \%$ which is also quite high. The highest market share was around $35.7 \%$. The average age of the listed firms in the data was around 11 years and this figure varies by about 6 years. The age range for the firms was 1 to 23 years. The average logged GDP stood at 10.36 with a standard deviation of 0.26 which, as expected, shows that there is a little variation in the values. 
The Family Ownership dummy variable showed an average value of 5.6\% which is skewed towards 0 . This shows that an overwhelming majority of the firms were not family owned. You would see further in the study that we could only analyze data on non-family firms due to this; we did not have enough data points to analyze family-owned firms because a very small minority are family owned are listed on the Ghanaian stock market.

For the Foreign Ownership variable, the average value was 33\%, thus the proportion of foreign-owned listed firms were less than locally owned firms, which is expected. We could say from the data that about $33 \%$ of the listed firms had some form of foreign ownership.

\subsection{Pairwise correlation}

We run a pairwise correlation, using listwise deletion to control for missing values and Bonferroniadjusted significance level to give is more significant results. The results are presented in Table 2. We find in the second column that our dependent variable (ROE) is weakly correlated with the independent variables, hence there is no indication of multicollinearity present in the data. But to further check for this, we do a VIF test (see appendix). The results show that the VIFs for each of our variables is below 4 , which is good. Also, the mean VIF for our data is 1.79 which is less than 4 so we do not further investigate, but can sufficiently conclude that our variables are not multilinear.

ROE is negatively correlated with Capital Intensity, Financial Risk, GDP and Family Ownership; with the strength relatively strong for Capital Intensity. Thus from the ROE column, Financial Risk and Capital Intensity negatively affect returns, Family-owned firms have more negative returns than Nonfamily owned whilst GDP also affects firm returns negatively.

Table 2

Correlation Matrix

\begin{tabular}{|c|c|c|c|c|c|c|c|c|c|c|c|}
\hline & ROE & Size & Capital Intensity & Liquidity & Financial Risk & Growth & Market share & Age & L.GDP & Family ownership & Foreign Ownership \\
\hline ROE & 1 & & & & & & & & & & \\
\hline Size & 0.1434 & 1 & & & & & & & & & \\
\hline Capital Intensity & -0.4348 & -0.2583 & 1 & & & & & & & & \\
\hline Liquidity & 0.1122 & -0.1168 & 0.2006 & 1 & & & & & & & \\
\hline Financial Risk & -0.0627 & 0.0067 & -0.0258 & -0.4915 & 1 & & & & & & \\
\hline Growth & 0.057 & 0.1226 & -0.175 & -0.0513 & -0.1334 & 1 & & & & & \\
\hline Market share & 0.3208 & 0.4868 & -0.3465 & -0.2236 & 0.0861 & 0.1474 & 1 & & & & \\
\hline Age & 0.2892 & 0.451 & -0.1961 & -0.3957 & 0.2075 & 0.0077 & 0.2897 & 1 & & & \\
\hline L.GDP & -0.0236 & 0.3175 & -0.0989 & -0.0458 & 0.1511 & -0.0917 & -0.0504 & 0.3869 & 1 & & \\
\hline Family Ownership & -0.1673 & -0.2643 & 0.095 & -0.0193 & -0.0083 & -0.021 & -0.1088 & -0.1458 & 0.0339 & 1 & \\
\hline Foreign Ownership & 0.3773 & 0.4588 & -0.1389 & -0.1502 & -0.0735 & 0.072 & 0.4559 & 0.679 & 0.0248 & -0.1283 & 1 \\
\hline
\end{tabular}

Size is weakly correlated, albeit positive, with ROE with a coefficient of $9.5 \%$. However, this does not measure causation, so we might not be able to assume Size is not a significant contributor of ROE for now. Size is also weakly and negatively correlated with Capital Intensity and Liquidity which is expected because a firm will have to divert funds into expansion in order to grow, leaving little funds to meet liquidity needs. Market Share positivity and slightly strongly correlates with Size which makes sense as big firms are most likely to have higher market shares than smaller ones. Size is also positively correlated with age as older firms would have experience and grow proportionately. Size is also negatively correlated with Family Ownership, indicating family ownership does not encourage an increase in size.

Capital Intensity is negatively correlated with Financial Risk, Growth, Age, GDP and Foreign Ownership, but the relationship is only slightly stronger in market share. It is however positively correlated with Liquidity. Liquidity exhibits a similar characteristic as Captial Intensity; it is negatively but weakly correlated with all the variables except Captial Intensity and ROE. Thus holding more liquid assets means the firm would have to compensate for financial risk, growth in assets, increase in size, market share and others.

Financial Risk is positively correlated with Market Share, Age and GDP, albeit the relationships are in their weak forms, and negatively correlated with Family Ownership and Foreign Ownership. Thus 
firms with higher market shares and age have lower financial risk. However, it negatively correlates with the Growth variable indicating taking more does not directly affect growth.

Market Share negatively, but weakly, affects GDP and Family Ownership. Thus family-owned firms have lower market shares and are younger firms (negative relationship with AGE). But with foreignowned firms, an increase in age positively affect the firm.

\subsection{Regression Results}

We do a pre-estimation test to see which estimation test, fixed effect or random effect, is appropriate. After running the Hausman test (see appendix), the test result showed a chi-square of 5.27 and $\mathrm{P}$ value of 0.5093 , therefore failing to reject the null hypothesis that the difference in coefficients not systematic. The random effects estimation model is appropriate in this case. Also, we test for heteroscedasticity by conducting the Breusch-Pagan / Cook-Weisberg test for heteroscedasticity (see appendix). The chi 2 probability for the test was 0.0001 signaling the variables do not have constant variance. Therefore we introduce robust standard errors in our models as a check.

We run five regression models;

1. Model one - Random Effects model on the pooled data set

2. Model two- Random Effects model on the pooled data set using robust standard errors to control for biases in the errors. This is also to serve as a check for robustness.

3. Model three- Random Effects model on non-family owned (listed firms) data set.

4. Model four - Random Effects model on foreign-owned (listed firms) data set.

5. Model five - Random Effects model on non-foreign owned (listed firms) data set.

Is indicated earlier there were very few data points for family-owned listed firms; thus very few familyowned firms are listed on the stock exchange. Therefore the data points were not enough for significant results to be produced. Using Random effects regression model the results are presented in Table 3. The R squared for the regression models range from $44 \%$ to $2 \%$; R squared is $23 \%$ for models 1 and 2 , $13 \%$ and $2 \%$ for models 3 and 4 , and $44 \%$ for model 5 . The low R squared is expected for the kind of data set we used for the study; panel data, consisting of a cross-section firms over a period of time. However, the Wald chi 2 and its probabilities, which shows the overall significance of the models, are statistically significant in each of the models. Thus, the results from the regressions are significant. SIZE has a negative relation with ROE for Non-family owned and Non-foreign owned listed firms but it's positive for Foreign-owned firms. However, the coefficient is not significant in all regressions models. Therefore, firm size is not a significant contributor to profitability for the listed firms. This result is consistent with the findings of Shamki et al (2016) and Dahmash (2015).

Capital Intensity is significant in all models; it is significant at 1\% in model 1, 3, 4, and 5, and at 5\% in model 2. The coefficients are negative in all 5 models, indicating an inverse effect on ROE for all listed firms irrespective of ownership types. Thus a firm's capital intensity negatively affects its profitability. From model 1, we can say that a listed firm's capital intensity negatively affects its profitability. Comparing the different ownerships (model 3 to 5), the coefficient for Non-foreign owned firms is the highest, indicating Capital Intensity has a higher effect on profitability for Non-foreign owned listed firms. Non-family owned listed firms have the coefficient.

Liquidity is also significantly positively related to profitability in all the models at $1 \%$ in models 1,3 , 4 , and 5 , and $5 \%$ in model 2 . From model 1 , the liquidity of listed firms positively affects their profitability (significant at 1\%) as a unit increase in liquidity will result in ROE increasing by 0.05 units. Comparing the ownership structures, liquidity has the highest effect on the ROE of Foreignowned firms, compared to the others. The small standard errors also indicate very small variations from the mean values (coefficients). As supported Abel and Le Roux (2016), Financial Risk has a positive 
effect on ROE in all the models, but significant in model 2 (at 5\%) and 5 (at 10\%). With a significance of $10 \%$ and a coefficient of 0.108 , Non-foreign firm's profitability (ROE) would increase by 0.108 units when its Financial Risk is increased by a unit. A standard error of 0.065 also tells us the variation in the coefficient is small. The firm's growth rate also positively affects its profitability in models 3 and 5 and effect reversed in models 1,2 and 4. However, the Growth variable is only significant in model 5 (at 10\%). Thus, growth in Non-foreign owned listed firms positively affects its profitability or returns.

Table 3

Regression one

\begin{tabular}{|c|c|c|c|c|c|}
\hline & & $\begin{array}{c}\text { Robust standard } \\
\text { Error }\end{array}$ & $\begin{array}{c}\text { Non-Family } \\
\text { Ownership }\end{array}$ & $\begin{array}{c}\text { Foreign } \\
\text { Ownership }\end{array}$ & $\begin{array}{c}\text { Non-Foreign } \\
\text { Ownership }\end{array}$ \\
\hline & (1) & (2) & (3) & (4) & (5) \\
\hline VARIABLES & roe & roe & roe & roe & roe \\
\hline Size & $\begin{array}{c}0.0159 \\
(0.0734)\end{array}$ & $\begin{array}{c}0.0159 \\
(0.0788)\end{array}$ & $\begin{array}{l}-0.0653 \\
(0.0693)\end{array}$ & $\begin{array}{c}0.114 \\
(0.137)\end{array}$ & $\begin{array}{l}-0.0457 \\
(0.0864)\end{array}$ \\
\hline Capital Intensity & $\begin{array}{c}-0.108 * * * \\
(0.0229)\end{array}$ & $\begin{array}{l}-0.108 * * \\
(0.0550)\end{array}$ & $\begin{array}{c}-0.0704 * * * \\
(0.0232)\end{array}$ & $\begin{array}{c}-0.107 * * * \\
(0.0364)\end{array}$ & $\begin{array}{c}-0.209 * * * \\
(0.0356)\end{array}$ \\
\hline Liquidity & $\begin{array}{c}0.0534 * * * \\
(0.0181)\end{array}$ & $\begin{array}{l}0.0534 * * \\
(0.0222)\end{array}$ & $\begin{array}{c}0.0499 * * * \\
(0.0169)\end{array}$ & $\begin{array}{l}0.149 * * \\
(0.0591)\end{array}$ & $\begin{array}{l}0.0405 * * \\
(0.0202)\end{array}$ \\
\hline Financial Risk & $\begin{array}{c}0.0902 \\
(0.0621)\end{array}$ & $\begin{array}{l}0.0902 * * \\
(0.0425)\end{array}$ & $\begin{array}{c}0.0547 \\
(0.0562)\end{array}$ & $\begin{array}{l}-0.123 \\
(0.244)\end{array}$ & $\begin{array}{c}0.108 * \\
(0.0650)\end{array}$ \\
\hline Growth & $\begin{array}{c}-0.000956 \\
(0.0107)\end{array}$ & $\begin{array}{l}-0.000956 \\
(0.00524)\end{array}$ & $\begin{array}{c}0.0223 \\
(0.0305)\end{array}$ & $\begin{array}{l}-0.00406 \\
(0.0387)\end{array}$ & $\begin{array}{l}0.0926^{*} \\
(0.0529)\end{array}$ \\
\hline Market Share & $\begin{array}{c}0.817 \\
(0.664)\end{array}$ & $\begin{array}{c}0.817 \\
(0.725)\end{array}$ & $\begin{array}{l}1.264 * * \\
(0.605)\end{array}$ & $\begin{array}{l}-0.152 \\
(0.385)\end{array}$ & $\begin{array}{c}1.707 \\
(1.098)\end{array}$ \\
\hline Age & $\begin{array}{c}0.0167^{*} \\
(0.00905)\end{array}$ & $\begin{array}{l}0.0167 * * \\
(0.00667)\end{array}$ & $\begin{array}{c}0.0162 * \\
(0.00833)\end{array}$ & $\begin{array}{l}0.0235 * \\
(0.0142)\end{array}$ & $\begin{array}{l}0.0257 * * \\
(0.0120)\end{array}$ \\
\hline L.GDP & $\begin{array}{c}-0.332 * * \\
(0.137)\end{array}$ & $\begin{array}{c}-0.332 * * \\
(0.141)\end{array}$ & $\begin{array}{l}-0.204 \\
(0.136)\end{array}$ & $\begin{array}{l}-0.416^{*} \\
(0.224)\end{array}$ & $\begin{array}{l}-0.352 * \\
(0.182)\end{array}$ \\
\hline Constant & $\begin{array}{l}3.248 * * \\
(1.278)\end{array}$ & $\begin{array}{c}3.248 * * * \\
(1.197)\end{array}$ & $\begin{array}{c}2.493 * * \\
(1.262)\end{array}$ & $\begin{array}{l}3.299 * \\
(1.821)\end{array}$ & $\begin{array}{c}3.915 * * \\
(1.711)\end{array}$ \\
\hline Observations & 136 & 136 & 120 & 41 & 83 \\
\hline Number of firms & 20 & 20 & 19 & 6 & 15 \\
\hline R Squared & 0.23 & 0.23 & 0.13 & 0.02 & 0.44 \\
\hline Wald Chi2 & 42.24 & 28.57 & 27.36 & 24.36 & 59.75 \\
\hline Chi2 Probability & 0.0000 & 0.0004 & 0.0006 & 0.0020 & 0.000 \\
\hline
\end{tabular}

Standard errors in parentheses

$* * * \mathrm{p}<0.01, * * \mathrm{p}<0.05, * \mathrm{p}<0.1$

Market Share positively affects ROE in models 1, 2, 3, and 5 albeit significant (at 5\%) only in model 3. For model 4, the relationship is negative and insignificant. For Non-family owned listed firms, a $1 \%$ increase in a firm's market share would result in profitability increasing by $1.26 \%$. The age of the firm significantly and positively affects its profitability in all models (significant at 10\%, 5\%, 10\%, 10\% and 5\% for models 1 through 5). Models 1 and 2 tells us that the age of listed firms does affect their profitability. Comparing the ownership structures (from model 3 through 5), age of the firm significantly affects the profitability of Foreign and Non-foreign listed firms more than Non-family owned firms. The standard error is higher for both Foreign and Non-foreign owned listed firms than for Non-family owned listed firms.

GDP has a negative effect on profitability in models $1,2,4$ and 5 at $5 \%, 5 \%, 1 \%$ and $1 \%$ significance level respectively. From model 1 and 2, GDP negatively affects the listed firm's profitability. Their standard errors show the coefficients are relatively spurious. Comparing the ownership structures, Foreign-owned listed firms seem to be more affected than Non-foreign owned listed firms.

To simplify, Table 4 further shows the relationship between the ownership structures. The gignificant relationships have been highlighted. 
Table 4

The relationship between the Ownership Structures

\begin{tabular}{|c|c|c|c|c|}
\hline & Listed firms (pooled) & Non-Family Ownership & Foreign Ownership & Non- Foreign Ownership \\
\hline Size & $+\mathrm{ve} /$ not significant & -ve/ not significant & $+v e$ / not significant & -ve/ not significant \\
\hline Capital Intensity & -ve/ significant & -ve/ significant & -ve/ significant & -ve/ significant \\
\hline Liquidity & $+v e /$ significant & +ve/ significant & +ve/ significant & +ve/ significant \\
\hline Financial Risk & +ve/ significant & $+\mathrm{ve} /$ not significant & -ve/ not significant & +ve/ significant \\
\hline Growth & -ve/ not significant & +ve/ not significant & -ve/ not significant & +ve/ significant \\
\hline Market Share & $+\mathrm{ve} /$ not significant & +ve/ significant & -ve/ not significant & $+\mathrm{ve} /$ not significant \\
\hline Age & $+v e /$ significant & +ve/ significant & +ve/ significant & +ve/ significant \\
\hline GDP & -ve/ significant & -ve/ not significant & -ve/ significant & -ve/ significant \\
\hline
\end{tabular}

\subsection{Ownership structure effects on profitability}

Next, we put the ownership structure variables (which are dummies) into our equation as predictors and test their effect on profitability. The regression model becomes;

$$
\begin{aligned}
& \text { roe }_{i t}=\partial_{i}+\beta_{1} \text { size }_{i t}+\beta_{2} \text { Captial intensity }_{i t}+\beta_{3} \text { liquidity }_{i t}+ \\
& \beta_{4} \text { financial risk }_{i t}+\beta_{5} \text { growth }_{i t}+\beta_{6} \text { marketshare }_{i t}+\beta_{7} \text { age }_{i t}+\beta_{8} g d p_{i t}+ \\
& \beta_{9} \text { familyownership }_{i t}+\beta_{10} \text { foreignownership }_{i t} \varepsilon_{i t}
\end{aligned}
$$

where familyownership and foreignownership are dummy variables for family ownership of listed firm ( $=1$ if family owned and 0 if otherwise) and foreign ownership of listed firm ( $=1$ if foreign owned and 0 if otherwise) respectively.

A Hausman test conducted on the model (see appendix) revealed that the differences in the coefficient were not systematic and there a random effects model is appropriate.

We run 6 regression models using OLS, Random effects and 3 stage least squares (and with robust standard errors as a check) in that order;

1. $\quad$ Model 1- Ordinary Least Squares (OLS)

2. $\quad$ Model 2 - Ordinary Least Squares (OLS) with robust standard errors

3. Model 3 - Random Effects model

4. $\quad$ Model 4 - Random Effects model with robust standard errors

5. $\quad$ Model $5-3$ Stage Least Squares

6. Model 6 - 3 Stage Least Squares using a Seemingly Unrelated Regression Estimation (SURE) method

The findings are presented in Table 5. The Wald chi2 probability and F probability for all models show that the models have a strong overall significance or high predictive significance. Also, the R-squared values for models 1,2 and 5,6 are $42 \%$ which tells us $42 \%$ of the variations in the predictors are explained by the predicted variable. These statistics show that our models are good enough to make statistic inferences from. Our variables of interest, ownership variables, are significant between 5 and $10 \%$. Family ownership is significant (at $5 \%$ ) in our random effects model but the relationship is negative signaling that family ownership has a negative effect on profitability. Thus, if a firm is family owned, its profits would be $30 \%$ lower compared to a non-family owned listed firm and this figure may vary by about $12 \%$. We think this is explained by the agency theory; as businesses with agents (or hired managers) acting on behalf of shareholders are most likely to do better than firms that are family owned and by extension, family managed. Family owned business tend to put family members, who may not necessarily have the required qualification, at the helm of affairs (thus top management positions) rather than hire qualified external persons to do so. 
Table 5

The results of Regression 2

\begin{tabular}{|c|c|c|c|c|c|c|}
\hline & OLS & OLS ROBUST & $\begin{array}{l}\text { RANDOM } \\
\text { EFFECTS }\end{array}$ & $\begin{array}{l}\text { RANDOM } \\
\text { EFFECTS } \\
\text { ROBUST }\end{array}$ & $\begin{array}{c}3 \text { STAGE } \\
\text { LEAST } \\
\text { SQUARES }\end{array}$ & SURE \\
\hline & (1) & (2) & (3) & (4) & (5) & (6) \\
\hline VARIABLES & roe & roe & roe & roe & roe & roe \\
\hline Size & $\begin{array}{c}-0.0915 * * \\
(0.0412)\end{array}$ & $\begin{array}{l}-0.0915^{*} \\
(0.0520)\end{array}$ & $\begin{array}{l}-0.0594 \\
(0.0763)\end{array}$ & $\begin{array}{l}-0.0594 \\
(0.0763)\end{array}$ & $\begin{array}{c}-0.0915 * * \\
(0.0393)\end{array}$ & $\begin{array}{c}-0.0915^{* *} \\
(0.0393)\end{array}$ \\
\hline Capital Intensity & $\begin{array}{c}-0.109 * * * \\
(0.0202)\end{array}$ & $\begin{array}{c}-0.109 * * * \\
(0.0324)\end{array}$ & $\begin{array}{c}-0.111 * * * \\
(0.0227)\end{array}$ & $\begin{array}{l}-0.111 * * \\
(0.0523)\end{array}$ & $\begin{array}{c}-0.109 * * * \\
(0.0193)\end{array}$ & $\begin{array}{c}-0.109 * * * \\
(0.0193)\end{array}$ \\
\hline Liquidity & $\begin{array}{c}0.0611 * * * \\
(0.0151)\end{array}$ & $\begin{array}{c}0.0611 * * * \\
(0.0140)\end{array}$ & $\begin{array}{c}0.0618 * * * \\
(0.0181)\end{array}$ & $\begin{array}{c}0.0618 * * * \\
(0.0222)\end{array}$ & $\begin{array}{c}0.0611 * * * \\
(0.0144)\end{array}$ & $\begin{array}{c}0.0611 * * * \\
(0.0144)\end{array}$ \\
\hline Financial Risk & $\begin{array}{c}0.0506 \\
(0.0647)\end{array}$ & $\begin{array}{c}0.0506 \\
(0.0391)\end{array}$ & $\begin{array}{c}0.0866 \\
(0.0604)\end{array}$ & $\begin{array}{c}0.0866^{* *} \\
(0.0422)\end{array}$ & $\begin{array}{c}0.0506 \\
(0.0618)\end{array}$ & $\begin{array}{c}0.0506 \\
(0.0618)\end{array}$ \\
\hline Growth & $\begin{array}{l}-0.00721 \\
(0.0358)\end{array}$ & $\begin{array}{l}-0.00721 \\
(0.0345)\end{array}$ & $\begin{array}{c}0.0259 \\
(0.0331)\end{array}$ & $\begin{array}{c}0.0259 \\
(0.0277)\end{array}$ & $\begin{array}{l}-0.00721 \\
(0.0342)\end{array}$ & $\begin{array}{l}-0.00721 \\
(0.0342)\end{array}$ \\
\hline Market Share & $\begin{array}{l}0.630 * \\
(0.346)\end{array}$ & $\begin{array}{l}0.630^{*} \\
(0.331)\end{array}$ & $\begin{array}{c}1.028 \\
(0.661)\end{array}$ & $\begin{array}{l}1.028 * \\
(0.621)\end{array}$ & $\begin{array}{l}0.630^{*} \\
(0.331)\end{array}$ & $\begin{array}{l}0.630 * \\
(0.331)\end{array}$ \\
\hline Age & $\begin{array}{l}0.0127^{* *} \\
(0.00624)\end{array}$ & $\begin{array}{c}0.0127^{*} \\
(0.00661)\end{array}$ & $\begin{array}{c}0.0163 \\
(0.0103)\end{array}$ & $\begin{array}{c}0.0163 \\
(0.0102)\end{array}$ & $\begin{array}{l}0.0127 * * \\
(0.00596)\end{array}$ & $\begin{array}{l}0.0127 * * \\
(0.00596)\end{array}$ \\
\hline L.GDP & $\begin{array}{c}-0.121 \\
(0.128)\end{array}$ & $\begin{array}{l}-0.121 \\
(0.153)\end{array}$ & $\begin{array}{c}-0.248 \\
(0.158)\end{array}$ & $\begin{array}{c}-0.248 \\
(0.194)\end{array}$ & $\begin{array}{l}-0.121 \\
(0.122)\end{array}$ & $\begin{array}{l}-0.121 \\
(0.122)\end{array}$ \\
\hline Family Ownership & $\begin{array}{l}-0.149 \\
(0.127)\end{array}$ & $\begin{array}{l}-0.149 \\
(0.248)\end{array}$ & $\begin{array}{c}-0.295 * * \\
(0.148)\end{array}$ & $\begin{array}{c}-0.295^{* *} \\
(0.120)\end{array}$ & $\begin{array}{l}-0.149 \\
(0.121)\end{array}$ & $\begin{array}{l}-0.149 \\
(0.121)\end{array}$ \\
\hline Foreign Ownership & $\begin{array}{c}0.134^{*} \\
(0.0755)\end{array}$ & $\begin{array}{c}0.134^{*} \\
(0.0757)\end{array}$ & $\begin{array}{c}0.00890 \\
(0.122)\end{array}$ & $\begin{array}{c}0.00890 \\
(0.125)\end{array}$ & $\begin{array}{c}0.134^{*} \\
(0.0721)\end{array}$ & $\begin{array}{c}0.134^{*} \\
(0.0721)\end{array}$ \\
\hline Constant & $\begin{array}{c}1.853 \\
(1.229)\end{array}$ & $\begin{array}{c}1.853 \\
(1.430)\end{array}$ & $\begin{array}{c}2.925 * * \\
(1.443)\end{array}$ & $\begin{array}{l}2.925^{*} \\
(1.661)\end{array}$ & $\begin{array}{l}1.853 \\
(1.174)\end{array}$ & $\begin{array}{c}1.853 \\
(1.174)\end{array}$ \\
\hline Observations & 124 & 124 & 124 & 124 & 124 & 124 \\
\hline R-squared & 0.420 & 0.420 & & & 0.420 & 0.420 \\
\hline Number of firms & & & 20 & 20 & & \\
\hline Number of obs. & 124 & 124 & 124 & 124 & 124 & 124 \\
\hline F statistic & 08.18 & 6.73 & & & 89.74 & \\
\hline F probability & 0.0000 & 0.0000 & & & 0.000 & \\
\hline Wald chi2 & & & 52.05 & 178.18 & & 89.74 \\
\hline Chi2 probability & & & 0.0000 & 0.0000 & & 0.0000 \\
\hline
\end{tabular}

Foreign ownership is also significant (at 10\%) in models 1, 2 and 5, 6. In this case, the coefficients are positive indicating foreign ownership has a positive effect on profitability. This result is similar to the findings of Bokpin (2013) albeit it refutes Peck-Ling, Nai-Chiek and Chee-Seong (2016). This figure tells us that when a firm is foreign owned, its profit increases by $13 \%$ compared to when it's not owned by foreigners and this varies by about $7 \%$ which is lower than that of family ownership. Thus foreignowned firms are more profitable than family-owned firms. We assume that this is due to the benefits that foreign firms may have over local forms; access to foreign capital and technology, variety of highly skilled labour, etc. We see also that after putting in the ownership variables, Size is significant at 1\% in the OLS and 3 Stage Least Squares models. For the random effect model (model 3 and 4), the relationship is not significant (results similar to what we found earlier). So we can say that firm size has a negative effect on profitability for listed firms. More research needs to be done to examine why this is so. Growth, however, is not significant in any of our models albeit the coefficients are negative for each case. GDP is also negative, as seen in the earlier regressions, however, the relationship is not significant in each case.

\subsection{Robustness Checks and Diagnostics}

We followed a number of standard procedures to ensure reliability and efficiency in the results and models estimated. First, to avoid outlier biases, we screen out outliers from our data, as confirmed by the summary statistic. Second, we employ the Pearson's correlation matrix whilst adopting listwise deletion and Bonferroni adjusted significance level to check for multicollinearity. Aside from this, we did a VIF test to further check for multicollinearity. Our mean VIF falls within acceptable levels showing our variables are not multicollinearity. Third, we employ a number of estimation strategies to ensure consistency and reliability in results across the different estimation strategies. We find consistency in the results presented across the models to a large extent; hence indicating that the results 
are reliable. Fourth, we use the robust standard errors approach to control for heteroskedasticity and autocorrelation to ensure the results are efficient. Fifth we employ a rich, more recent annual panel data consisting of 23 listed companies over 11 years. Therefore the results adequately reflect trends in the stock market. These procedures and standards ensure our results are reliable, accurate, efficient and fit or good for generalization in the context of listed firms in Ghana.

\section{Summary and Conclusion}

This study examines the possible effects of ownership structure on profitability of listed firms between 2003 and 2013. The study is motivated by the agency theory and the need to examine the effect of separation of ownership and management. Employing a panel data of 23 listed firms in Ghana and using a static regression model (OLS, Random Effects and 3 Stage Least Squares), we find that Ownership Structure does affect profitability. Whilst capital intensity and liquidity negatively and positively affected profitability in the ownership forms examined (non-family, foreign and non-foreign ownership), financial risk and growth positively affected profitability for non-foreign owned listed firms only. Market share only positivity affected profitability for non-family owned listed firms whilst firm age positively affected profitability for all the 3 forms of ownership examined. GDP is also seen to negatively affect profitability for foreign and non-foreign owned listed firms but the relationship is not significant for non-family owned firms. These findings are supported by the agency theory which posits that separation of ownership and management, though may lead to agency problems, can positively affect profits. When we examine the impact of ownership structure on profitability, we see that family-owned listed firms make 30\% less profits compared to non-family owned ones, whilst foreign-owned firms make $13 \%$ more profits than non-foreign owned ones. This finding has significant implications for Ghanaian listed firms. Thus, foreign collaborations or ownership increases profits by a margin of $13 \%$ therefore listed firms should consider giving some part of ownership to foreign firms because they can help grow the company's profits. On the other side, family-owned firms that are listed do not perform well, in terms of profits, compared to non-family owned or foreign ones. Therefore family owned listed firms should consider diluting ownership in order to save the company and grow more profits.

\section{References}

Abel, S. \& Le Roux, P. (2016). Determinants of banking sector profitability in Zimbabwe? International Journal of Economics and Financial Issues, 6(3), 845-854

Alchian, A.A. (1965). Some economics of property rights. Il Politico 30, 816-829.

Altunbas, Y., Evans, L., \& Molyneux, P. (2001). Bank ownership and efficiency. Journal of Money, Credit and Banking 33, 926-954.

Athanasoglou, P. P., Brissimis, S. N., \& Delis, M. D. (2008). Bank-specific, industry-specific and macroeconomic determinants of bank profitability. Journal of international financial Markets, Institutions and Money, 18(2), 121-136.

Balsmeier, B., \& Czarnitzki, D. (2017). Ownership concentration, institutional development and firm performance in Central and Eastern Europe. Managerial and Decision Economics, 38(2), 178-192.

Berger, A. N., Miller, N. H., Petersen, M. A., Rajan, R. G., \& Stein, J. C. (2005). Does function follow organizational form? Evidence from the lending practices of large and small banks. Journal of Financial Economics, 76(2), 237-269.

Bearle Jr., Means, G.C., (1932). The Modern Corporation and Private Property. Macmillan, New York.

Bokpin, G. A. (2013). Ownership structure, corporate governance and bank efficiency: an empirical analysis of panel data from the banking industry in Ghana. Corporate Governance: The International Journal of Business in Society, 13(3), 274-287.

Brooks, C. (2008). Introductory financial econometrics.

Chang, S. J. (2003). Ownership structure, expropriation, and performance of group-affiliated companies in Korea. Academy of Management Journal, 46(2), 238-253. 
Dahmash, F. N. (2015). Size effect on company profitability: Evidence from Jordan. International Journal of Business and Management, 10(2), 58-72

Demsetz, H., \& Villalonga, B. (2001). Ownership structure and corporate performance. Journal of Corporate Finance, 7(3), 209-233.

Dietrich, A., \& Wanzenried, G. (2011). Determinants of bank profitability before and during the crisis: Evidence from Switzerland. Journal of International Financial Markets, Institutions and Money, 21(3), 307-327.

Eisenhardt, K. M. (1989). Agency theory: An assessment and review. Academy of Management Review, 14(1), 57-74.

Fama, E.F. and M.C. Jensen. 1983. Separation of Ownership and Control. Journal of Law and Economics, 26, 327-349.

Freeman, R. E. (1984). Strategic management: A stakeholder perspective. Boston: Pitman, 13.

Freeman, R. E., Gilbert, D. R., \& Hartman, E. (1988). Values and the foundations of strategic management. Journal of Business Ethics, 7(11), 821-834.

Friedman, M. (1970). A theoretical framework for monetary analysis. Journal of Political Economy, 78(2),193-238.

Fries, S., \& Taci, A. (2005). Cost efficiency of banks in transition: Evidence from 289 banks in 15 postcommunist countries. Journal of Banking and Finance, 29, 55-81.

Gedajlovic, E., \& Shapiro, D. M. (2002). Ownership structure and firm profitability in Japan. Academy of Management Journal, 45(3), 565-575.

Greene, W. (1993). Econometric Analysis. New York: MacMillan Publishing Co.

Hamilton, G. G., \& Biggart, N. W. (1988). Market, culture and authority: A comparative analysis of management and organization in the Far-East. American Journal of Sociology, 94, S52

Han, K. C., \& Suk, D. Y. (1998). The effect of ownership structure on firm performance: Additional evidence. Review of Financial Economics, 7(2), 143-155.

Iannotta, G., Nocera, G., \& Sironi, A. (2007). Ownership structure, risk and performance in the European banking industry. Journal of Banking \& Finance, 31(7), 2127-2149.

Jensen, M.C., W. Meckling. (1976). Theory of the firm: Managerial behavior, agency costs, and ownership Structure. Journal of Financial Economics 3 (October): 305-360.

Jensen, M. C. (1993). The modem industrial revolution, exit, and the failure of internal control systems. Journal of Finance, 48 (July): 831-880.

Kapopoulos, P., \& Lazaretou, S. (2007). Corporate ownership structure and firm performance: evidence from Greek firms. Corporate Governance: An International Review, 15(2), 144-158.

Kasman, A. (2010). Consolidation and competition in the banking industries of the EU member and candidate countries. Emerging Markets Finance and Trade, 46(6), 121-139.

Kochan, T. A., \& Rubinstein, S. A. (2000). Toward a stakeholder theory of the firm: The Saturn partnership. Organization science, 11(4), 367-386.

Kosak, M., \& Cok, M. (2008). Ownership Structure and Profitability of the Banking Sector: The Evidence from the SEE-6 Region.

Kotey, R., Akomatey, R., \& Kusi, B. A. (2019). Data for: Ownership structure and Profitability of listed firms in an Emerging market, Mendeley Data, V2.

Kusi, B. A., Gyeke-Dako, A., \& Agbloyor, E. K. (2017). Bank profitability determination in income brackets in Africa: a shareholder versus stakeholder perspective. African Finance Journal, 19(2), 29-46.

Kwan, S.H. (2004). Risk and return of publicly held versus privately owned banks. Federal Reserve Bank of New York Economic Policy Review 10, 97-107.

Mangena, M., Tauringana, V., \& Chamisa, E. (2012). Corporate boards, ownership structure and firm performance in an environment of severe political and economic crisis. British Journal of Management, 23, S23-S41.

McConnell, J. J., \& Servaes, H. (1990). Additional evidence on equity ownership and corporate value. Journal of Financial Economics, 27(2), 595-612. 
Micco, A., Panizza, U., \& Yanez, M. (2004). Bank Ownership and Performance. Inter-American Development Bank Working Paper No. 518.

Milgrom, P. R., \& Roberts, J. D. (1992). Economics, organization and management.

Morck, R., Shleifer, A., \& Vishny, R. W. (1988). Management ownership and market valuation: An empirical analysis. Journal of Financial Economics, 20, 293-315.

Naceur, S. B., \& Omran, M. (2011). The effects of bank regulations, competition, and financial reforms on banks' performance. Emerging Markets Review, 12(1), 1-20.

Peck-Ling, T., Nai-Chiek, A., \& Chee-Seong, L. (2016). Foreign ownership, foreign directors and the profitability of Malaysian listed companies. Procedia-Social and Behavioral Sciences, 219, 580588.

Phung, D. N., \& Mishra, A. V. (2016). Ownership structure and firm performance: Evidence from Vietnamese listed firms. Australian Economic Papers, 55(1), 63-98.

Shamki, D., Alulis, I. K. \& Sayari, K. (2016). Financial information influencing commercial bank profitability. International Journal of Economics and Finance, 8(6), 166-174.

Shleifer, A., \& Vishny, R. W. (1997). A survey of corporate governance. Journal of Finance, 52, 737783.

Terraza, V. (2015). The effect of bank size on risk ratios: Implications of banks' performance. Procedia Economics and Finance, 30, 903-909.

Wooldridge, J. M.(2009): Introductory econometrics: a modern approach. Publisher: South-Western.

$\mathrm{Yu}$, M. (2013). State ownership and firm performance: Empirical evidence from Chinese listed companies. China Journal of Accounting Research, 6(2), 75-87.

Xia, F., \& Walker, G. (2015). How much does owner type matter for firm performance? Manufacturing firms in China 1998-2007. Strategic Management Journal, 36(4), 576-585.

\section{Appendix}

\section{VIF Test}

The Variance Inflation Factor measures how much the variance is inflated, which in effect tests for multicollinearity as variables with inflated variances are multicollinear. We conducted a VIF test on our independent variables (variables of interest). The findings are presented in the table below;

\begin{tabular}{llllll}
\hline Variable & VIF & 1/VIF & Variable & VIF & $1 /$ VIF \\
\hline Age & 3.27 & 0.306120 & Financial Risk & 1.48 & 0.673627 \\
Foreign Ownership & 2.84 & 0.352353 & Capital Intensity & 1.22 & 0.816670 \\
Size & 1.88 & 0.532952 & Family Ownership & 1.13 & 0.887263 \\
Market share & 1.73 & 0.578778 & Growth & 1.09 & 0.919153 \\
Liquidity & 1.67 & 0.598560 & Mean VIF & 1.79 & \\
L.GDP & 1.64 & 0.609773 & & & \\
\hline
\end{tabular}

The VIFs for each of the predictors were between 1.09 and 3.27, which are very low. The standard practice that VIFs of 4 and above need to be further investigated, whilst those exceeding 10 are signs of serious multicollinearity requiring correction. Since all our variables have VIFs less than 4, it's safe to conclude there is no correlation in our variables.

\section{Test for Heteroscedasticity}

As a pre-estimation test, we test for heteroscedasticity by conducting the Breusch-Pagan / CookWeisberg test for heteroscedasticity. This test checks if the standard errors are biased or not. A biased standard error indicates that the independent variables may be heteroscedastic. The null hypothesis is the variance the errors are constant and the alternate hypothesis is the variance are not constant. After running the test, the findings are here presented; Breusch-Pagan / Cook-Weisberg test for heteroscedasticity 


$$
\text { Prob }>\text { chi } 2=0.0001
$$

The $\mathrm{P}$ value is less than 0.05 which means it is significant so we reject the null hypothesis and conclude that the errors do not have a constant variance. Therefore we have to use models with robust standard errors.

\section{Hausman Test}

We conducted a Hausman test on the models to see if fixed or random effects regression model is appropriate for the analysis. The null hypothesis for the test is the difference in coefficients not systematic and the alternate hypothesis is that the difference in coefficients is systematic. We run the test on both models. The tables are presented below;

\section{Regression one}

\begin{tabular}{|c|c|c|c|c|}
\hline & $\begin{array}{l}\text { (b) } \\
\text { fe }\end{array}$ & $\begin{array}{l}\text { (B) } \\
\text { re }\end{array}$ & $\begin{array}{l}\text { (b-B) } \\
\text { Difference }\end{array}$ & $\begin{array}{l}\text { sqrt(diag(V_b-V_B })) \\
\text { S.E. }\end{array}$ \\
\hline Size & .10616 & -.0179644 & .1241244 & .1032362 \\
\hline Capital Intensity & -.1186042 & -.1069202 & -.011684 & .0131672 \\
\hline Liquidity & .0364104 & .0480655 & -.0116551 & .0104861 \\
\hline Financial Risk & .0007172 & .0002723 & .0004449 & .0004051 \\
\hline Growth & .0001878 & .0002013 & -.0000136 & .000046 \\
\hline Market share & .8004802 & .9133686 & -.1128884 & 1.072555 \\
\hline age & .0175989 & .0189485 & -.0013496 & .0197569 \\
\hline L.GDP & -.414863 & -.3007562 & -.1141067 & .225638 \\
\hline
\end{tabular}

Test: Ho: difference in coefficients not systematic

Chi2(6) $=(\mathrm{b}-\mathrm{B})^{\prime}\left[\left(\mathrm{V} \_\mathrm{b}-\mathrm{V} \_\mathrm{B}\right)^{\wedge}(-1)\right](\mathrm{b}-\mathrm{B})=5.27$

Prob $>$ Chi-Square $=\overline{0} .50 \overline{9}$

Because the p-value is more than 0.50 , we fail to reject the null hypothesis and conclude that a random effects model is appropriate.

\section{Regression two (with ownership structure as variables)}

\begin{tabular}{|c|c|c|c|c|}
\hline & $\begin{array}{l}\text { (b) } \\
\text { fe }\end{array}$ & $\begin{array}{l}\text { (B) } \\
\text { re }\end{array}$ & $\begin{array}{l}\text { (b-B) } \\
\text { Difference }\end{array}$ & $\begin{array}{l}\text { sqrt(diag(V_b-V_B })) \\
\text { S.E. }\end{array}$ \\
\hline Size & .2407976 & -.0593851 & .3001827 & .142508 \\
\hline Capital Intensity & -.1156273 & -.111066 & -.0045613 & .0125489 \\
\hline Liquidity & .0605887 & .0618068 & -.0012181 & .0111671 \\
\hline Financial Risk & .1760932 & .0865881 & .0895051 & .0400166 \\
\hline Growth & .0265775 & .0259262 & .0006513 & .0135927 \\
\hline marketshare & .9935596 & 1.027677 & -.0341178 & 1.026403 \\
\hline age & -.0078115 & .0162728 & -.0240843 & .0204347 \\
\hline L.GDP & -.2839185 & -.2484391 & -.0354794 & .2259266 \\
\hline Family Ownership & -.2901982 & -.2950392 & .004841 & .1173418 \\
\hline Foreign Ownership & -.280738 & .0089016 & -.2896396 & .1848548 \\
\hline
\end{tabular}

Because the p-value is more than 0.50, we fail to reject the null hypothesis and conclude that a random effects model is appropriate.

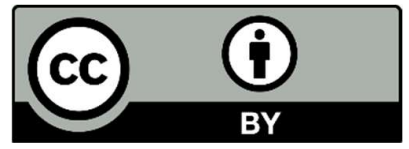

(C) 2020 by the authors; licensee Growing Science, Canada. This is an open access article distributed under the terms and conditions of the Creative Commons Attribution (CC-BY) license (http://creativecommons.org/licenses/by/4.0/). 